\title{
VAUCHERIA SPECIES FROM SELECTED REGIONS IN POLAND
}

\author{
JOANNA ŻELAZNA-WIECZOREK \\ Department of Algology and Mycology, University of Łódź \\ Banacha 12/16, 90-237 Łódź, Poland \\ e-mail: zelazna@taxus.biol.uni.lodz.pl
}

(Received: December 28, 2000. Accepted: Jannuary 30, 2002)

\begin{abstract}
Observations on morphological features, distribution and environmental preferences of ten species of the Vaucheria genus are presented on the basis of research carried out between 1989 and 1995 at 42 localities in central Poland, the Opole Silesia, as well as individual sites in Poland. New taxa may be distinguished on the basis of observations of the more comprehensive variability of taxonomic features. Seasonal preferences and habitat conditions that influence the development of sexual organs, which are the basis of taxonomy of this genus, were determined. The following species occurred frequently in the material collected: V. sessilis, V. terrestris, V. geminata, $V$. hamata. On the other hand: $V$. dichotoma, $V$. verticillata, $V$. aversa, $V$. undulata, $V$. walzi, $V$. woroniniana, were found sporadically throughout the observations.
\end{abstract}

KEY WORDS: Vaucheria, morphological features, occurrence in Poland, environmental preferences.

\section{INTRODUCTION}

Vaucheria de Candolle is the only genus that belongs to the monotypic order Vaucheriales, class Xanthophyceae, phylum Chrysophyta (Rieth 1980). It comprises ca. 100 taxa, listed in world literature in the 19th and 20th centuries. Starmach (1972) lists 28 species in Europe, and Rieth (1980) 32 species. The Vaucheria genus is widespread, and its representatives occur in various habitats, both fresh- and salt-water ones.

Taxa of the Vaucheria genus are rarely mentioned from Poland. Frequently, the data comprise a small area or are listed only in floristic studies as it is necessary to collect sexual organs on site or to set laboratory cultures to identify species. The taxonomic features are: distribution of sexual organs, oogonia and antheridia, on filaments, their dimensions and the filament width where sexual organs develop.

Species that belong to the Vaucheria were determined in algological material by Polish researchers: Gutwiński, Eichler, Cybulski, Łopot and Kozłowski (Kadłubowska 1961), already at the end of the 19th century. Subsequent data on the occurrence of Vaucheria species were given at the beginning of the 20th century by Gutwiński and Raciborski.

These algae were found in more comprehensive floristic studies for the current territory of Poland, often occurring as a random element, and usually described only up to the level of genus. Kawecka (1971) listed this genus from the High Tatra. Mrozińska (1957) determined Vaucheria geminata, $V$. racemosa, $V$. aversa among filiform algae growing over higher plants in fish ponds in Ochaby. Kadłubowska (1961) reported $V$. sessilis, $V$. geminata, $V$. uncinata, $V$. terrestris from the neighbourhood of Łódź. Pliński (1973) listed the occurrence of $V$. terrestris, $V$. hamata and $V$. sessilis from the areas of salt flats near Łęczyca. Skalna (1973) lists $V$. sessilis in a karst spring in the KrakowskoCzęstochowska Upland, and $V$. pachyderma among soil algae that occur in vegetable farming (Skalna 1979). Siemieniak (1983/1984) recorded three localities from the Czarna Przemsza river in Upper Silesia, where she identified: $V$. geminata, V. sessilis and V. walzi. Kadłubowska (1964), Kalinowska-Kucharska and Ligowski (1976), Rakowska (1984), Ligowski (1986, 1988, 1991), Żelazna-Wieczorek and Kadłubowska (1994) observed the occurrence of the Vaucheria genus in Central Poland. Kadłubowska et al. (1991) listed the occurrence of $V$. geminata, V. sessilis and Vaucheria sp. in the Widawka river in Central Poland. More comprehensive studies on algae of the Vaucheria genus were conducted by Amirowicz (1980, 1983a, 1983b) only in the neighbourhood of Cracow and in the KrakowskoCzęstochowska Upland. Mrozińska (1991), Wołowski (1992), Nawrat (1993) observed the occurrence of the taxa of the Vaucheria in this area.

The data concerning the occurrence of the Vaucheria genus in Poland gathered so far have inspired the author to commence research on this group of algae. Morphological variability and biology of the taxa of this genus are also presented in this publication. The objective of the study is to describe the variability of taxonomic features, distribution and environmental preferences for the growth and reproduction of the identified taxa of Vaucheria. 


\section{MATERIAL AND METHODS}

The study material was collected between 1989 and 1995. Fragments of thalli were transferred to containers. Depending on the place of occurrence, thalli were either transferred with a piece of the substrate (e.g. moist soil) or sampled in water (collected from water). The material collected was surveyed in the laboratory and next subdivided into three parts: one was fixed; the two other were removed to crystallisation basins. Laboratory cultures were conducted for the period between six weeks and six months. It was necessary to vary the level of water in crystallisation basins for the samples that had been taken at localities where habitat conditions differed, e.g. the water flow, depth, etc. In the case of live material, it was determined whether Vaucheria filaments occurred in the samples collected and whether filaments with sexual organs or only vegetative filaments occurred in the material collected. The material with sexual organs made the basis for the identification of the taxon. Features necessary to identify species were measured at least 30 times for each sample from one population.

The distribution of localities at which Vaucheria species occurred, on the basis of the author's own research, is presented on the ATPOL grid square system (Zając 1978).

Analyses of chemical composition and physical properties of water for 20 localities in which continuous observations were carried out were conducted in 1994. The analysis of physical properties and chemical composition of water for localities 1-15 was performed by the Laboratory of Biology at the University of Łódź, and for localities 1620 by the Laboratory of "Blachownia" Chemical Works in Kędzierzyn-Koźle.

\section{Study Area}

The area of study comprised the neighbourhood of Łódź, the territory of the Opole Silesia, the area of Kujawy, Bielsko-Biała province, Żelazowa Wola and the Wigierski National Park. In all, 354 samples were collected. The

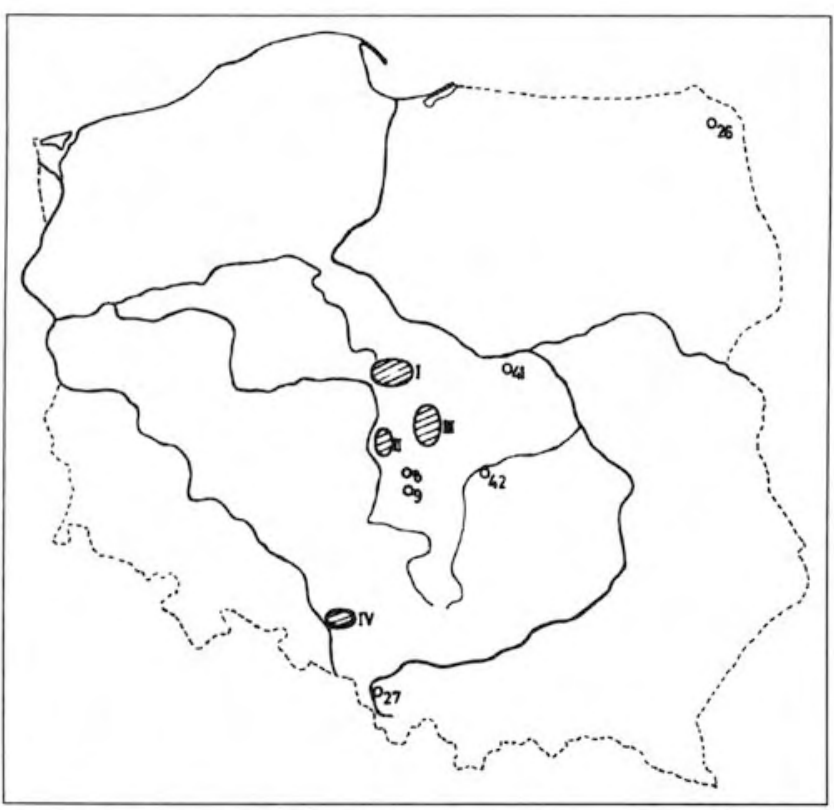

Fig 1. Distribution of localities in selected regions in Poland. Area I - loc. 28 - 39; area II - loc. 1, 6, 7, 23, 25; area III - loc. 2 $-5,10-15,24$; area IV - loc. $16-22$. study material was collected at localities 1-20 at which continuous observations were carried out, and at localities 21-42 at which one or a few samples were collected. The distribution of sampling sites is shown in Fig. 1.

\section{LOCALITIES}

1 (DD 54) - Pełczyska near Ozorków; comprises flood waters around the encased chlorine and sodium well (Pliński 1969). Sampling dates: $1992-01.04 ; 20.05 ; 03.06 ; 24.06 ; 09.10 ; 1993-$ $15.04 ; 15.06 ; 17.08 ; 1994-26.04 ; 21.06 ; 07.09$; $05.10 ; 1995$ $16.06 ; 24.08$.

2 (DD 46) - Gieczno I - the canal connecting fish ponds. Samples were taken both from the water and from the moist, muddy embankment. Sampling dates: $1992-01.04 ; 20.05 ; 03.06$; $24.06 ; 09.10 ; 1993$ - 15.04; 15.06; 14.07; 09.09; 1994 - 26.04; $21.06 ; 11.07 ; 04.08 ; 17.09 ; 05.10 ; 09.11 ; 1995-16.06$.

3 (DD 46) - Gieczno II - field water-course, periodically drying. Sampling dates: $1992-03.06 ; 24.06 ; 09.10 ; 1993-15.04$; $15.06 ; 14.07 ; 09.09 ; 1994$ - 26.04; 21.06; 11.07; 04.08; 07.09; $05.10 ; 09.11 ; 1995-16.06$.

4 (DD 36) - Młogoszyn I - a drainage ditch with flood waters. Sampling dates: 1992 - 01.04; 20.05; 03.06; 24.06; 09.10; 05.11; 1993 - 15.04; 15.06; 14.07; 17.08; 1994 - 26.04; 21.06; 11.07; 04.08; 07.09; 05.10; 09.11; 1995 - 16.06.

5 (DD 36) - Młogoszyn II - a drainage ditch. Sampling dates: 1992 - 01.04; 20.05; 03.06; 24.06; 09.10; $05.11 ; 1993$ - 15.04; $15.06 ; 14.07 ; 17.08 ; 1994$ - 26.04; $21.06 ; 11.07 ; 04.08 ; 07.09$; $05.10 ; 09.11 ; 1995-16.06$.

6 (DD 74) - Lutomiersk - the Zalewka (Wrząca) river. On the sampling site, the bottom is sandy and the embankment high. Sampling dates: $1992-12.08 ; 29.09 ; 1993-27.04 ; 03.06 ; 06.07$; $24.08 ; 10.11 ; 1994-06.05 ; 08.07 ; 09.08 ; 27.09 ; 03.11 ; 1995$ $05.04 ; 10.05 ; 04.10$.

7 (DD 84) - Wodzierady - the Pisia river. The river bottom is sandy and rocky, and the current rapid on the sampling site. Sampling dates: 1992 - 12.08; 29.09; 1993 - 27.04; 03.06; (06.07; $14.09 ; 10.11 ; 1994-06.05 ; 08.07 ; 09.08 ; 27.09 ; 03.11 ; 1995$ $05.04 ; 10.05 ; 04.10$.

8 (DE 06) - Karczmy - the Grabia river, in the regulated section of the course on the anti-erosion river bar (Maksymiuk 1970). The material was collected both from the bar and below it. Sampling dates: $1992-12.08 ; 29.09 ; 1993-27.04 ; 03.06 ; 06.07$; $24.08 ; 14.09 ; 10.11 ; 1994-06.05 ; 08.07 ; 09.08 ; 27.09 ; 03.11$; $1995-05.04 ; 10.05 ; 04.10$.

9 (DE 25) - Widawka - the Widawka river. The river bed is made of concrete on the sampling site, and the water flow rate equals from 0.6 to $1 \mathrm{~m} / \mathrm{s}$ (Ligowski 1988). Sampling dates: 1993 - 27.04.; 03.06; 06.07; 24.08; 10.11; 1994 - 06.05; 08.07; 09.08; $27.09 ; 03.11 ; 1995-05.04 ; 10.05 ; 04.10$.

10 (DD 66) - Dobieszków, samples were taken from the moist, shaded embankment of the Struga Dobieszkowska. Sampling dates: 1993 - 15.04; 14.05; 15.06; 09.09; 1994 - 30.05; 11.07 ; $07.09 ; 12.10 ; 09.11 ; 1995-12.04 ; 16.06$.

11 (DD 66) - Dobra - a natural water course. Sampling dates: 1992 - 22.04; 17.07; 15.10; 1993 - 15.04; 09.09; $1994-30.05$; $11.07 ; 09.07 ; 12.10 ; 1995-12.04 ; 16.06$.

12 (DD 47) - Psary. Samples were taken from the moist, muddy embankment, as well as from water in the canal that carries off water from the fish ponds. Sampling dates: $1992-22.04$; $29.05 ; 03.07 ; 15.10 ; 1993-07.05 ; 24.06 ; 14.07 ; 17.08 ; 09.09$; $26.10 ; 1994-30.05 ; 11.07 ; 04.08 ; 15.09 ; 12.10 ; 09.11 ; 1995$ $12.04 ; 28.09$.

13 (DD 37) - Walewice. Samples were taken near the dam in the main canal that feeds fish ponds. Water flows over the dam in 
this place and flows down over the concrete riverbed and next over stones. Sampling dates: $1992-22.04 ; 29.05 ; 03.07 ; 15.10$; 1993 - 07.05; 24.06; 14.07; 17.08; 09.09; 26.10; $1994-30.05$; $11.07 ; 04.08 ; 15.09 ; 12.10 ; 09.11 ; 1995-12.04 ; 28.09$.

14 (DD 48) - Okręt - the canal that carries off water from fish pond. Samples were taken in the part of the canal made of concrete. Sampling dates: $1992-22.04 ; 29.05 ; 03.07 ; 15.10 ; 1993-$ $14.05 ; 24.06 ; 17.08 ; 09.09 ; 26.10 ; 1994-30.05 ; 21.06 ; 04.08$; $15.09 ; 12.10 ; 1995-12.04 ; 28.09$.

15 (DD 58) - Lubianków near Głowno - a regulated natural water course Brzuśnia; the bottom is muddy and the embankments overgrown with vascular plants. Sampling dates: 1992 $05.04 ; 29.05 ; 03.07 ; 09.09 ; 1993-25.04 ; 30.06 ; 14.09 ; 1994-$ $17.04 ; 06.05 ; 30.05 ; 14.07 ; 23.09 ; 1995-12.04$.

16 (CF 37) - Biały Potok - the river in Kędzierzyn-Koźle, flows through forest areas passing a waste heap with sludge from the chemical works. Samples were taken below the waste heap. Sampling dates: $1992-22.09 ; 25.10 ; 1993-30.07 ; 10.10 ; 1994$ - $02.05 ; 31.07 ; 02.10 ; 1995-26.03 ; 08.05 ; 23.07$.

17 (CF 37) - Kłodnica - the river in Kędzierzyn-Koźle. Samples were taken in a bend with a high embankment. Sampling dates: $1992-29.03 ; 22.09 ; 25.10 ; 1993-30.07 ; 10.10 ; 1994-$ $02.05 ; 31.07 ; 02.10 ; 1995-26.03 ; 08.05 ; 23.07$.

18 (CF 37) - Stary Kanał/culvert - in Kẹdzierzyn-Koźle. Samples were taken from the culvert made up of pipes, from which water flows rapidly over stones. Sampling dates: $1992-$ $29.03 ; 22.09 ; 25.10 ; 1993$ - 30.07; 10.10; 1994 - 02.05; 31.07; $02.10 ; 1995-26.03 ; 08.05 ; 23.07$.

19 (CF 38) - Bierawka - a river in the village of Grabówka. Coke plants and mines are the chief source of pollution in the river. Samples were taken from the moist river embankment and from the shallow littoral zone. Sampling dates: $1992-22.09$; $25.10 ; 1993$ - $31.07 ; 10.10 ; 1994-02.05 ; 31.07 ; 02.10 ; 1995$ $26.03 ; 08.05 ; 23.07$.

20 (CF 37) - Stara Kuźnia - a natural water course that flows through forest areas. Samples were taken where the course is divided by a dike, with a culvert enclosed by wooden boards. Sampling dates: $1992-22.09 ; 25.10 ; 1993-31.07 ; 10.10 ; 1994$ - 02.05; 31.07; 02.10; 1995 - 26.03; 08.05; 23.07.

21 (CF 38) - Stary Kanał/mill - in Kẹdzierzyn-Koźle. On the sampling site, water flow down over wooden beams that were covered with Vaucheria thalli. Sampling date: 1989 - 26.05.

22 (CF 37) - Kẹdzierzyn-Koźle/tent - a garden foil tent, the area $18 \mathrm{~m}^{2}, 2 \mathrm{~m}$ high, in a house garden. Samples were taken from moist soil. Sampling dates: 1992 - 29.03; 23.09; 1993 30.07 .

23 (DD 54) - Pełczyska/meadow. Periodical. Flood waters supplied by rainwater appear in the meadow in spring and vanish after ca. 6 weeks. Sampling dates: $1992-22.04$; $1993-15.04$.

24 (DD 57) - Głowno/forest. The material was sampled from the canal connecting two ponds in the forest. Sampling date: 1992 -31.05 .

25 (DD 64) - Bełdów - a water course that carries off water from fish ponds. Sampling dates: $1992-08.07 ; 29.09$.

26 (FB 09) - Kamionka/Wigry - the Kamionka river in Leszczewo. The river is variable; the current picks up speed along the course and becomes character of a mountain stream. Sampling date: $1993-28.05$.

27 (DF 91) - Gołysz. Material was sampled on various sites in the fish farm, on embankments of water courses and canals that regulate water flow among the ponds. Sampling dates: 1994 23.07; 01.10; $1995-04.05$.

28-39 - Kujawy - in the area of southern Kujawy. Scattered bigger heights and small hills contrast with numerous pits that remained after blocks of dead ice had melted. Their area ranges between some twenty square meters or more and a few hectares.
The depth of field lakes ranges between 2 and 10 meters (Kucharski 1993). Study material was sampled at 12 localities selected from stagnant water tanks, both from moist soil, on the edge of the water table, and from the water. Sampling dates: Błenna (28 - DD 01) - 1994 - 19.05; 08.09; 1995 - 31.05; 15.09; Tymień (29 - DD 01) - 1994 - 26.05; 1995 - 21.06; 19.08; Śmielnik (30 - DD 01) - 1994 - 26.05; 1995 - 20.06; 19.08; Rzeżewo I (31 - DD 03) - 1994 - 01.07; 20.10; 1995 - 19.04; 07.07; 16.10; Rzeżewo II (32 - DD 03) - 1994 - 01.07; 20.10; 1995 - 19.04; 07.07; Rzeżewo III (33 - DD 03) - 1994 - 01.07; 1995 - 19.04; 18.09; Kromszewice (34 - DD 03) - 1994 - 19.05; 08.09; 1995 - 19.04; 07.07; 15.09; Osiecz Mały (35 - DD 02) 1994 - 19.05; 08.09; 1995 - 19.08; Morzyce I (36 - DD 04) $1994-16.07 ; 14.10 ; 1995-19.04 ; 07.07 ; 18.09 ;$ Morzyce II (37 - DD 04) - 1994 - 16.07; 14.10; 1995 - 19.04; 07.07; 29.08; Mielno (38 - DD 03) - 1994 - 20.10; 1995 - 26.05; 18.09; Ignalin (39 - DD 03) - 1994 - 14.10; 1995 - 26.05; 26.06; 18.09 .

40 (DD 96) - Wolbórka - the source of the Wolbórka river. Sampling date: $1994-13.07$.

41 (ED 21) - Utrata/Żelazowa Wola - in the park. Material was sampled from the shoal overgrown with vascular plants. Sampling date: $1995-03.07$.

42 (EE 01) - Niebieskie Źródła - the sampling site was located on the embankment of the side canal in in Tomaszów Mazowiecki. Sampling date: $1995-19.05$.

A number of groups may be differentiated on the basis of the results of the analysis of physical properties and chemical composition of water at the localities examined. Locality 1 is highly conspicuous - flood waters supplied directly by water from a salt-water source. The localities chosen along rivers are also very characteristic and may be divided into two groups: highly polluted - localities 9, 16, 17, 19, and clean (the author considers the water to be clean if the parameters examined comply with the standards of cleanness categories in the Resolution of the Ministry of Environmental Protection, Natural Resources and Forestry of 5th of Nov., 1991) - localities 6, 7, 8, 10, 20. Localities situated in canals that regulate the level of water in fishponds constitute a separate group as the concentration of nitrogen compounds is higher there - localities 2,$3 ; 4,5,12,13 ; 14,15$. Locality 11 is a small water course that cannot be classified within the groups named above. Locality 18 is a strongly polluted, cannot be placed in one of the above categories either.

\section{DESCRIPTION OF THE IDENTIFIED TAXA OF VAUCHERIA}

\section{Vaucheria dichotoma (L.) C.A. Agardh 1817}

synonym Vaucheria dichotoma (L.) Martius 1817 including Vaucheria starmachii Kadłubowska in Starmach 1972

Vaucheria dichotoma was collected at one locality - 1 Pełczyska. Vaucheria filaments formed thick clumps firmly attached to the substrate with rhysoids in the flood waters surrounding the encased well on the muddy substrate. When the level of water was high, clumps formed loose filaments, directed towards the surface of the water, dark green; when the level of water was low, filaments in clumps were compacted, dark green, with white deposit, salt crystals, brittle. During the summer, the area covered 


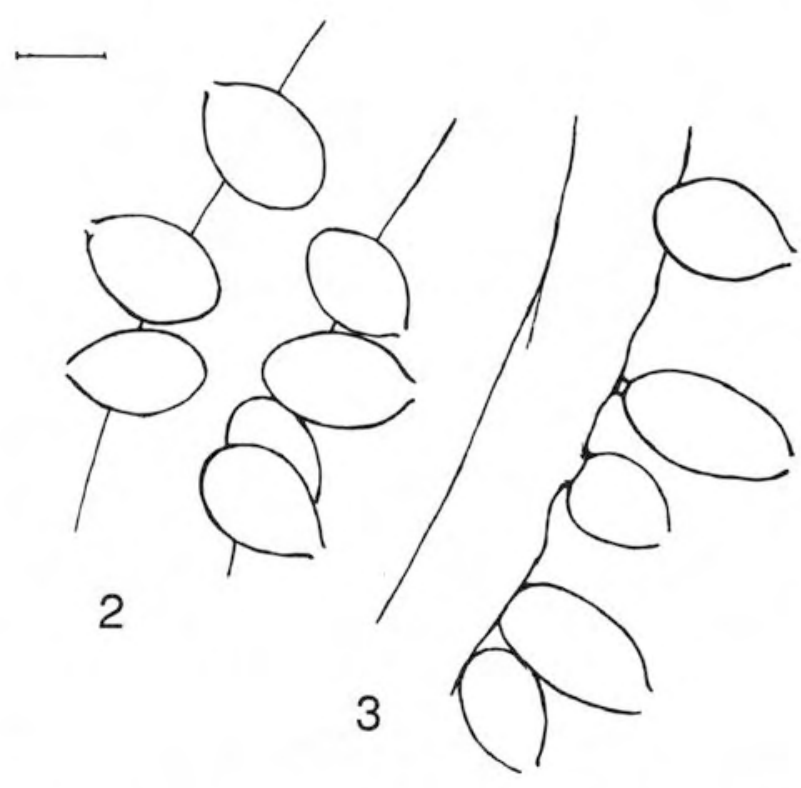

Figs 2-3. Vaucheria dichotoma - antheridia, a few together in groups. Scale bar $-100 \mu \mathrm{m}$.

by clumps of Vaucheria diminished every year. This is connected with a continual decrease in the water level in the flood waters the surface of which is significantly smaller that given by Pliński (1969).

The samples in which filaments with sexual organs occurred were collected on $01.04 .92 ; 26.04 .94 ; 21.06 .94$. Only vegetative filaments were collected on the other sampling days. Only $V$. dichotoma was identified in Pełczyska. Sexual organs developed in spring and early summer in natural conditions; sexual organs, however, did not develop in cultures.

Sexual organs were distributed along the filament, oogonia and antheridia together, but far from each other, some times separately on different filaments. Antheridia were variously distributed on the filament: individually, up to two; scattered along the filament; a few together, but in groups also distributed along the filament far from one another; numerous in groups, densely distributed (Figs 2-3). Oogonia were distributed individually, far from one another along the filament.

In the case of $V$. dichotoma, as only this species was identified at loc. 1, the dimensions of the generative filament and the vegetative filament could be compared. The width range of both filaments overlaps. Oogonium dimensions: length 302.4-482.0 $\mu \mathrm{m}$, width 280.8-417.6 $\mu \mathrm{m}$; antheridium: length 118.8-226.8 $\mu \mathrm{m}$, width 64.8-140.4 $\mu \mathrm{m}$; filament diameter 75.6-259.2 $\mu \mathrm{m}$, of the specimen collected in Pełczyska do not differ from those specified in literature (Starmach 1972; Zauer 1977; Rieth 1980). The diameter of the vegetative filament ranges between 86.4 to $226.8 \mu \mathrm{m}$.

\section{Vaucheria aversa Hassall 1843}

Vaucheria aversa was sampled at two localities. Filaments of this species occurred in water and on moist soil, as well as on the mud in the littoral zone of fresh water tanks. Generative filaments were collected in the area at loc. 4 - Młogoszyn: 01.04.92; 20.05.92; 12.04.95; at loc. 13 - Walewice only on 29.05.92. The sampling days in the case of loc. 4 on which filaments with sexual organs were collected were characterised by low water temperature $\left(4-7^{\circ} \mathrm{C}\right)$ and low air temperature $\left(3-7^{\circ} \mathrm{C}\right)$, and on 12.04.92 the water surface was covered with a thin film of ice, and Vaucheria occurred then only as thick cottony mats, totally submerged in water. On 29.05 .92 at loc. 13 air temperature equaled $17^{\circ} \mathrm{C}$, water temperature $7^{\circ} \mathrm{C}$, and filaments of $V$. aversa occurred as thick mats in the littoral zone, partly submerged in water.

In the collection places of $V$. aversa thalli with sexual organs on other sampling days, at loc. 4 thalli that occurred on the verge of water and moist soil were observed, the level of water varied significantly throughout the year, the area of the flood waters was limited as a result of which dried thalli or no thalli at all occurred on the embankment during the summer. At loc. 13; the level of water changed abruptly a few times throughout the year so that Vaucheria thalli were found dried or were not observed at different times of the year.

The life span of the filaments from these localities was approximately 8 weeks in cultures, and sexual organs did not develop.

Sexual organs were grouped along the filament: one oogonium and two antheridia on both sides; 2 oogonia and 2 antheridia, and oogonium rostra were directed towards the antheridia; 3 oogonia between 2 antheridia, and the edge oogonia were directed towards the adjacent antheridia while middle ones were directed randomly. The frequency of occurrence of the sexual organs distribution types listed in the population of 12.04 .95 in the material examined of
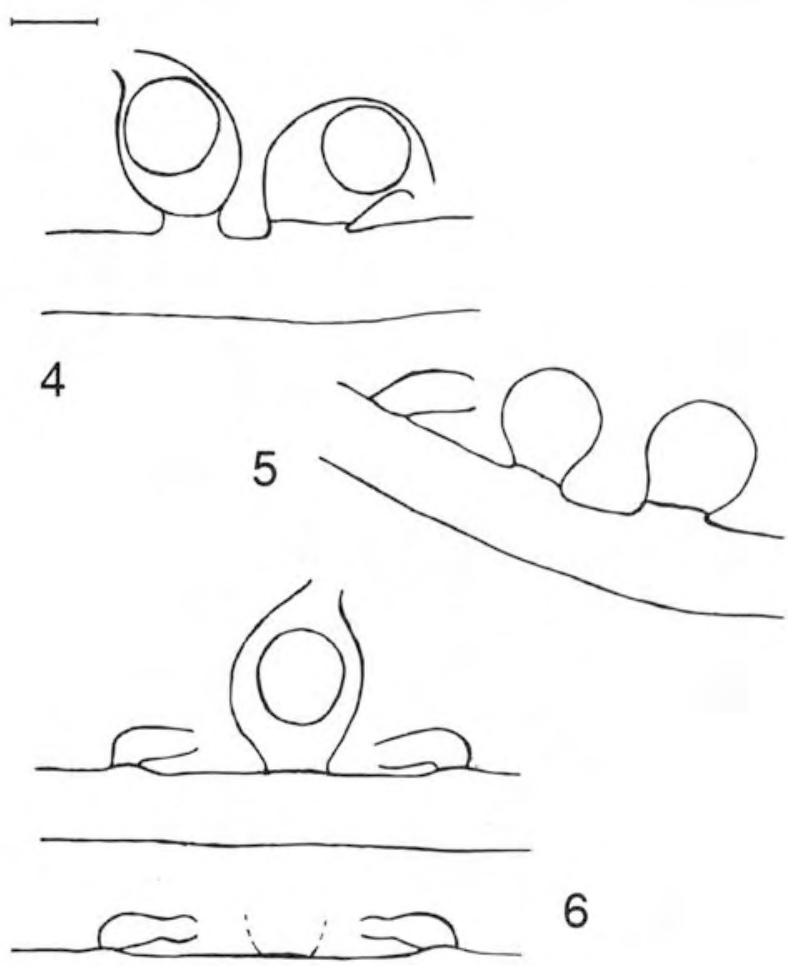

6

Fig. 4. Vaucheria avers $a$ - two oogonia. Scale bar $-100 \mu \mathrm{m}$.

Fig. 5. Vaucheria aversa - developing sexual organs. Scale bar $100 \mu \mathrm{m}$.

Fig. 6. Vaucheria aversa - antheridia with a narrowing at $1 / 3$. Scale bar $-100 \mu \mathrm{m}$. 
53 groups was as follows: 1 oogonium +2 antheridia -23 groups; 2 oogonia +2 antheridia -28 groups; 3 oogonia + 2 antheridia -2 groups.

In the examined populations, the oogonium shape differed from straight to fully developed forms with a curved rostrum, directed towards the main filament (Fig. 4). Adjacent oogonia within one group were very frequently differently developed. Sexual organs were developed (Fig. 5 ). The development of antheridia preceded that of oogonia. Antheridia were initially positioned $45-90^{\circ}$ in relation to the main filament and parallel to the main filament as they developed. In some cases antheridia with a narrowing at $1 / 3$ of the antheridium were observed in different population (Fig. 6). Oospores that were observed in the material were suspended in the oogonium, ball or ellipse-shaped. Oospores fell off together with oogonia. Oogonium dimensions: length 121.8-208.8 $\mu \mathrm{m}$, width 104.4-156.6 $\mu \mathrm{m}$; antheridia: length 81.2-116.0 $\mu \mathrm{m}$, width $29.0-40.6 \mu \mathrm{m}$; oospores: length 75.4-121.8 $\mu \mathrm{m}$, width 58.0-104.4 $\mu \mathrm{m}$ and the filament diameter 52.6-104.4 $\mu \mathrm{m}$, are in keeping with literature (Starmach 1972; Zauer 1977; Rieth 1980).

Vaucheria sessilis (Vaucher) de Candolle in de Lamarck et de Candolle 1805

synonym Vaucheria bursata (O.F. Müller) C.A. Agardh 1812

Vaucheria sessilis was collected at 27 localities. Filaments with sexual organs were collected at the following localities: loc. 2 - 21.06.92, 16.06.95; loc. 3 03.06.92, 09.11.94; loc. 5 - 05.06.94; loc. 6 - 03.06.93, 06.07.93; loc. 7 - 24.08.93; loc. 8 - 03.06.93, 06.05.94, 08.07.94; loc. 9 - 05.04.95; loc. 10 - 15.04.93, 16.06.95; loc. 11 - 30.05.94; loc. 12 - 22.04.92, 07.05.93, 24.06.93; loc. 13 - 30.05.94; loc. 14 - 14.05.93; loc. 16 - 23.09.92; loc. 17 - 02.10.94; loc. 21 - 26.05.89; loc. 24 - 31.05.92; loc. 25 - 08.07.92, 29.09.92; loc. 27 - 04.05.95; loc. 28 19.05.94, 08.09.94, 31.05.95; loc. 29 - 21.06.95; loc. $32-$ 01.07.94, 20.10.94; loc. 34 - 19.04.95; loc. 35 - 21.06.95; loc. 37 - 14.10.94; loc. 38 - 20.10.94, 18.09.95; loc. $40-$ 13.07.94; loc. $42-19.05 .95$. In the case of loc. 4 , the species was determined only on the basis of a laboratory culture.

$V$. sessilis was collected at localities where habitat conditions varied, chiefly in canals that regulate the water level in fish ponds, polluted waters, but also in clean waters. $V$. sessilis shows high ecological tolerance.

Sexual organs in this species develop in natural conditions mainly in late spring, and to a lesser degree in autumn (Fig. 7).

The dimension range of the vegetative filament: diameter 23.2-145.0 $\mu \mathrm{m}$ and sexual organs, oogonium: length 46.4$121.8 \mu \mathrm{m}$, width 46.4-98.6 $\mu \mathrm{m}$; antheridium: length 17.4$40.6 \mu \mathrm{m}$, in the material studied is broad. Differences in the dimensions of filaments and sexual organs in the material collected at one locality (8), sampled on various days, are significant. In the sample collected on 03.06.1993, the filament diameter 34.8-40.6 $\mu \mathrm{m}$, oogonium length 52.2-58.0 $\mu \mathrm{m}$, oogonium width 46.4-52.2 $\mu \mathrm{m}$, antheridium length $17.4 \mu \mathrm{m}$; and in the sample collected 06.05.1994 the filament diameter 104.4-145.0 $\mu \mathrm{m}$, oogonium length 98.6$121.8 \mu \mathrm{m}$, oogonium width 87.0-92.8 $\mu \mathrm{m}$, antheridium width $40.6 \mu \mathrm{m}$. In the material collected on 22.04 .1992 at

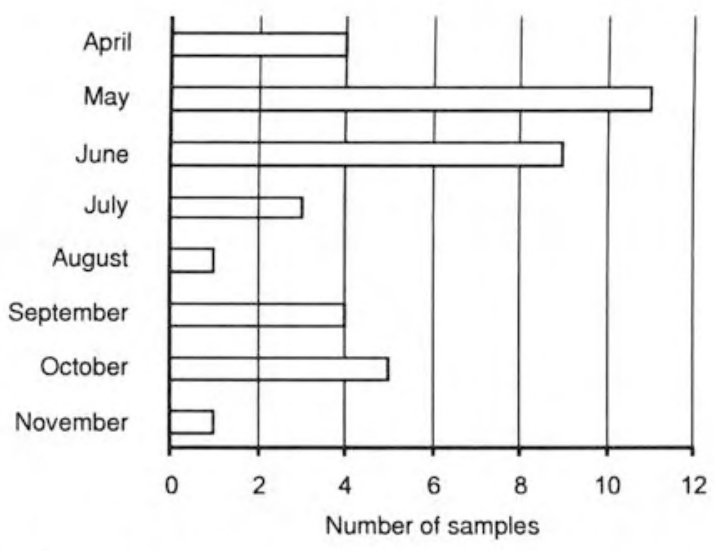

Fig. 7. Vaucheria sessilis - the number of samples in which generative filaments were found in the subsequent months.

locality 12 , oogonium dimensions diverge from those specified in literature and equal: length $46.4 \mu \mathrm{m}$, width 46.4 $\mu \mathrm{m}$. In the material collected at loc. 7 - Wodzierady, an additional opening was observed in the antheridium, which had not been described in literature (Fig. 8). The opening developed on the upper, external side of the antheridium. In the samples collected in Gołysz on 04.05.1995, filaments with sexual organs developed on the end part (Fig. 9), and the dimensions of the vegetative filament and sexual organs are in keeping with those given in literature.
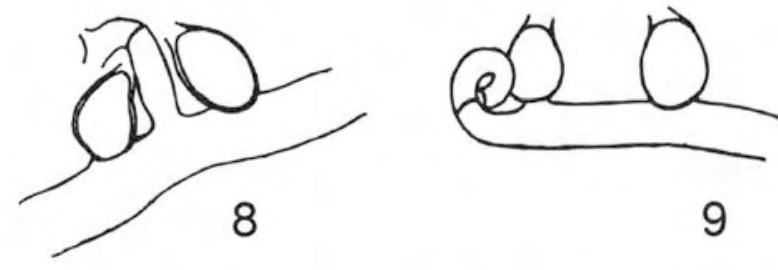

Fig. 8. Vaucheria sessilis - antheridium with additional opening. Scale bar $-100 \mu \mathrm{m}$.

Fig. 9. Vaucheria sessilis - sexual organs developed at the end of the filament. Scale bar $100 \mu \mathrm{m}$.

In the studied material, a great variability of the oogonium shape, from described as f. clavata to f. sessilis and f. repens, was noticed. In the populations examined, oogonia of various shapes occurred within the groups of sexual organs. Thus, it is not possible to differentiate forms within this species.

In the samples collected at localities where $V$. sessilis was identified on the basis of laboratory cultures, synzoospores developed intensively after a few days (3-7) and they germinated after 3-7 more days. Synzoospores developed intensively when the temperature difference between the site and the laboratory equaled $15^{\circ} \mathrm{C}$, mainly in spring months. Synzoospore dimensions: length 162.4-185.6 $\mu \mathrm{m}$, width 133.4-145.0 $\mu \mathrm{m}$, are in keeping with literature (Starmach 1972; Zauer 1977). Sexual organs were developed, antheridium first and then oogonia.

Vaucheria geminata (Vaucher) de Candolle, in de Lamarck et de Candolle 1805

Vaucheria geminata was collected at 17 localities. The material containing generative filaments was collected at 


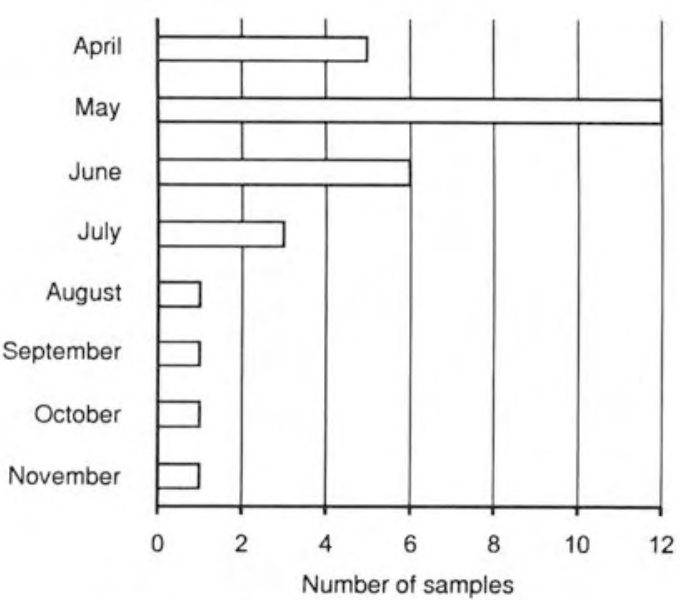

Fig. 10. Vaucheria geminata - the number of samples in which generative filaments were found in the subsequent months.

the localities: loc. $2-30.09 .91,21.06 .92,15.04 .93$, 09.11.94, 16.06.95; loc. 4 - 01.04.92, 20.05.92, 24.06.92; loc. 5 - 24.06.92, 21.06.94, 11.07.94, 05.10.94, 24.08.95; loc. 6 - 06.07.93, 08.07.94; loc. 10 - 15.04.93; loc. 11 30.05.94; loc. 12 - 24.06.93, 30.05.94; loc. $13-29.05 .92$, 07.05.93; loc. 14 - 29.05.92; loc. 18 - 08.05.95; loc. 24 -31.05 .92 ; loc. $26-28.05 .93$; loc. $28-31.05 .95$; loc. $30-$ 26.05.94; loc. 33 - 19.04.95; loc. 36 - 19.04.95; loc. $38-$ 26.05.95.

The species occurred mainly on moist embankments of various water courses, periodically submerged, and also in shallow tanks of stagnant water. The localities at which $V$. geminata was collected are characterised by increased trophy, some of them, however, are poor in nutrients.

The species develops sexual organs in natural habitats chiefly in spring time (Fig. 10).

In cultures, the species developed sexual organs in samples from loc.: $2,4,5,6,11$. The time needed to develop sexual organs in cultures varied between 2 weeks to 6 months. Dimensions of vegetative filaments and sexual organs in the material in cultures differed from the sexual organs in the material collected from natural habitats at the same localities.

The diameter of vegetative filament $34.8-110.2 \mu \mathrm{m}$ and the antheridium width $23.2-58.0 \mu \mathrm{m}$ in the populations studied is in keeping with the data in literature (Starmach 1972; Zauer 1977; Rieth 1980). Oogonium dimensions: length 69.6-156.6 $\mu \mathrm{m}$, width 52.2-116.6 $\mu \mathrm{m}$, are greater than the values specified by Rieth (1980). Significant dimension differences in populations from different localities were observed, and the difference of extreme dimensions was twice as big. In the material from loc. 14 29.05.1992: filament diameter 34.8-52.2 $\mu \mathrm{m}$; oogonium length 69.6-81.2 $\mu \mathrm{m}$, and width 52.2-63.8 $\mu \mathrm{m}$; antheridium width 23.2-40.6 $\mu \mathrm{m}$; and from loc. 30 - 26.05.94: filament diameter 46.4-75.4 $\mu \mathrm{m}$; oogonium length 127.6-156.6 $\mu \mathrm{m}$, and width 98.6-116.6 $\mu \mathrm{m}$; antheridium width 40.6-58.0 $\mu \mathrm{m}$. In the material collected from loc. $11-30.05 .94$, sexual organs were developed in a different way. Apart from typical generative branches on the mother filament, oogonia and antheridia were developed at the end of the mother filament (Fig. 11). Outgrow also took place in the material from this locality. It occurred on generative branches and a new branch with sexual organs developed where normally oogonium should be. In the material from loc. 13 collected

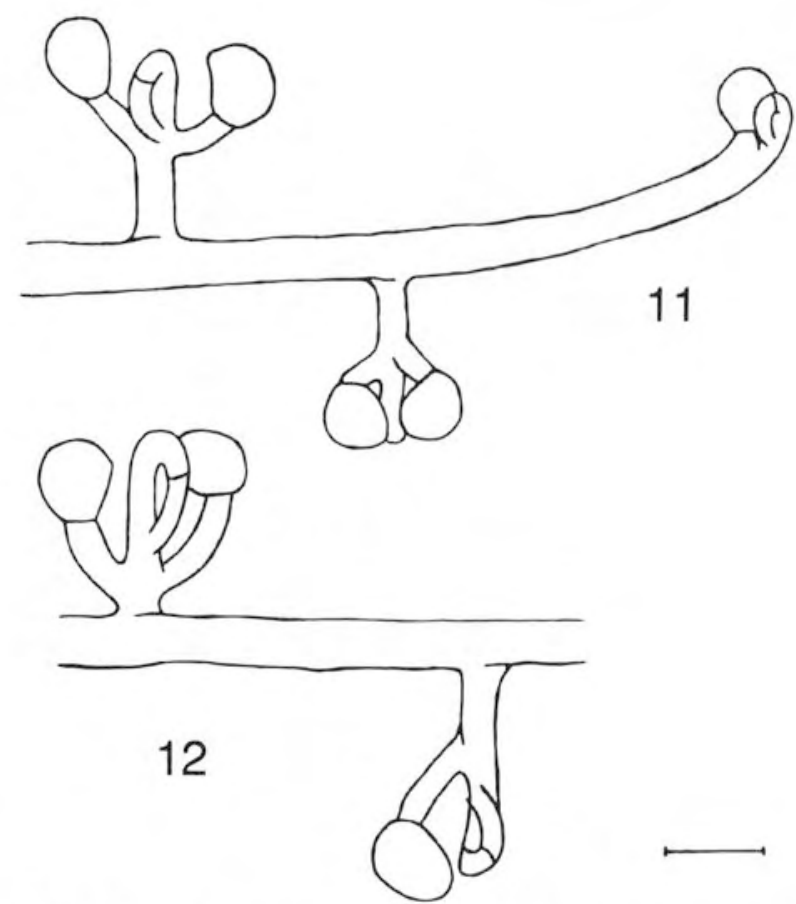

Fig. 11. Vaucheria geminata - sexual organs developed at the end of the filament. Scale bar $-100 \mu \mathrm{m}$.

Fig. 12. Vaucheria geminata - generative branches with one oogonium and two oogonia. Scale bar $-100 \mu \mathrm{m}$.

on 29.05.92, on the other hand, a generative branch with one oogonium was developed in the population in approximately half the cases (Fig. 12).

Aplanospoores, observed in the material examined, were noticeably elongated; and their ratio between their length and width depended on the time of the measurement and the moment they left the aplanosporangium. The ratio between the aplanospoore length and width ranges between $3.4: 1$ and 1.5:1.

\section{Vaucheria verticillata Meneghini sensu Kützing 1856}

Vaucheria verticillata was identified at one locality: 6 Lutomiersk. The species was determined on the basis of the culture conducted between 29.09 .92 till 15.03.93. The culture from the material collected from the moist embankment of a water course, that contained only vegetative filaments was set in a crystallisation basin in which a low water level was maintained so that the filaments protruded over the water.

The diameter of vegetative filaments $69.0-104.4 \mu \mathrm{m}$ in the material studied is slightly wider than that specified in literature (Starmach 1972; Zauer 1977; Rieth 1980), while oogonium dimensions: length $81.2-92.8 \mu \mathrm{m}$, width $63.8-$ $69.6 \mu \mathrm{m}$, are in keeping with those given by Zauer (1977) and Rieth (1980). In the population observed, 3 to 5 oogonia with long stems grouped together occurred on the generative branches. Oogonia are positioned in a typical way, all of them on the branches are slightly bent and turned in one direction (Fig. 13).

\section{Vaucheria undulata Jao 1936}

Vaucheria undulata was identified at two localities. Vaucheria filaments that come from these localities 

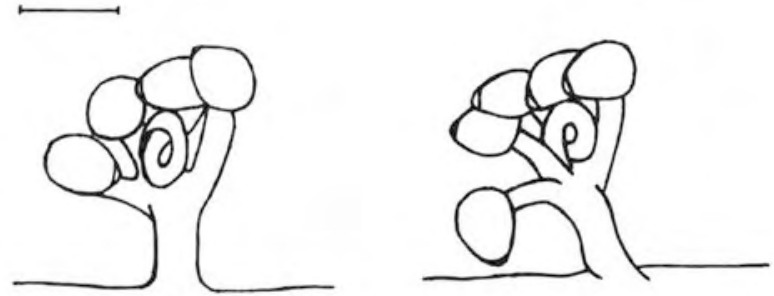

Fig. 13. Vaucheria verticillata - a generative branches. Scale bar $-100 \mu \mathrm{m}$

occurred on moist soil, on the embankment of the canal that carries off water from fish ponds at loc. 27 - Gołysz, as well as the damp, periodically flooded river embankment at loc. 10 - Dobieszków.

Filaments with sexual organs were collected at loc. 10 on $30.05 .94 ; 07.09 .94 ; 12.10 .94$. On the other sampling days, filaments in the generative stage did not occur and in summer months (June - September 1993; July 1994), Vaucheria filaments were not found at all. $V$. undulata at loc. 27 sampled on 04.05.95 was determined on the basis of the culture on 14.10.95.

Oogonia in the material examined usually occurred individually, less frequently two of them on the branch with sexual organs. In the material from loc. 27 , there were 36 generative branches with one oogonium for 45 studied, and 9 with two oogonia (Fig. 14). Numerous, fine dark brown spots covered mature oospores. The antheridium was twisted screw-wise, positioned below the oogonium, or between two oogonia if that was the case. Young vegetative and generative filaments were visibly undulatory in the top sections but also in further sections, very old parts of the filament with a thick cell wall being the only exception (Fig. 15). As for the material from loc. 27 in the culture, when the substrate dried up periodically the cell wall of $V$. undulata filaments was thicker, with visible layering. The filament diameter 34.6-58.0 $\mu \mathrm{m}$, oogonium dimensions: length
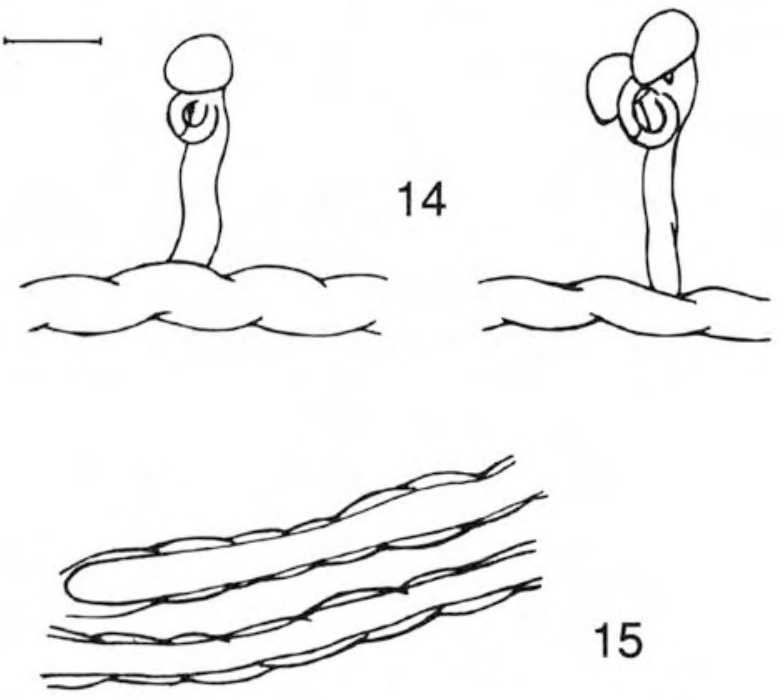

Fig. 14. Vaucheria undulata - generative branches with one or two oogonia. Scale bar $-100 \mu \mathrm{m}$.

Fig. 15. Vaucheria undulata - undulatory filaments. Scale bar $100 \mu \mathrm{m}$.
58.0-87.0 $\mu \mathrm{m}$, width 52.2-81.2 $\mu \mathrm{m}$ and the antheridium width 17.4-23.2 $\mu \mathrm{m}$, do not diverge from those specified in literature (Starmach 1972; Zauer 1977; Rieth 1980).

Vaucheria terrestris sensu Götz 1897

synonym Vaucheria frigida (Roth) C.A. Agardh 1824

Vaucheria terrestris was collected at 18 localities. Generative filaments were collected at the localities: loc. 2 - 21.06.92; loc. 4 - 15.04.93, 16.06.95; loc. 5 - 05.10.94; loc. 6 - 06.05.94, 08.07.94; loc. 7 - 03.06.93, 24.08.93; loc. 8 - 27.04.93, 10.05.95; loc. 10 - 15.04.93, 12.10.94; loc. 12 - 22.04.92, 07.05.93, 24.06.93, 15.09.94; loc. 13 30.05.94; loc. 16 - 02.05.94, 02.10.94; loc. 23 - 15.04.93; loc. 32 - 20.10.94, 19.04.95; loc. 33 - 19.04.95; loc. $35-$ 19.08.95; loc. $36-19.04 .95$.

Filaments of this species were collected mainly from moist soil in the immediate vicinity of stagnant water tanks, as well as from the moist embankment of the water course. The sites were submerged in water during the spring. At loc. 23 water stayed during early spring and came from thaw water. At loc. $6,8,27,34 \mathrm{~V}$. terrestris filaments occurred in water and formed loose, cottony agglomerations. The material sampled from water was sterile; sexual organs were developed in a laboratory culture. At loc. 7, on the other hand, Vaucheria filaments grow over stones splashed with water.

In natural habitats, the species develops sexual organs chiefly in early spring and autumn, when water temperature is low (Fig. 16).

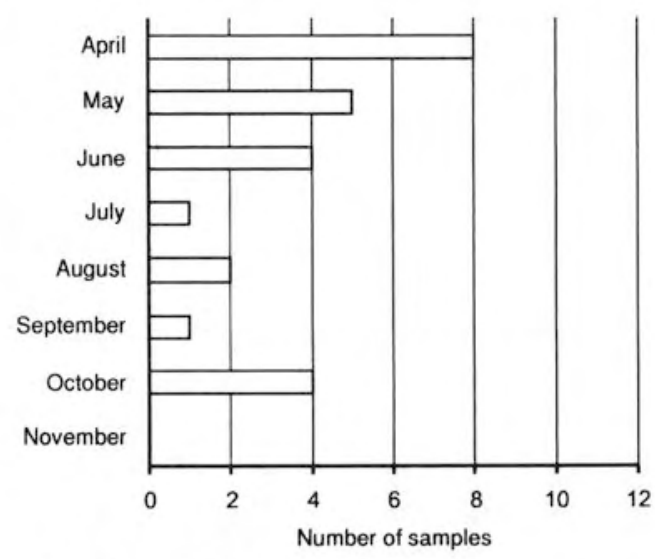

Fig. 16. Vaucheria terrestris - the number of samples in which generative filaments were found in the subsequent months.

The material from loc. 22 was determined on the basis of a culture; sexual organs were developed after 8 weeks. The material was collected from moist soil, close to the tent walls, in early spring on 29.03.92. Sexual organs began to develop in the material collected at loc. 27 after 5 months of being in a culture, and at loc. 34 - after 4 weeks.

In the material examined, the branch with sexual organs was typical and in keeping with data in literature. The process of branch development was observed in the material from loc. 7 and 16; first, the antheridium develops and then the oogonium above it. The process of outgrow of the branch with sexual organs at the place were the oogonium usually develops was observed in the population from loc. 8 (Fig. 17). The vegetative filament diameter $34.8-87.0 \mu \mathrm{m}$ and the antheridium width $23.2-40.6 \mu \mathrm{m}$ in the populations examined 


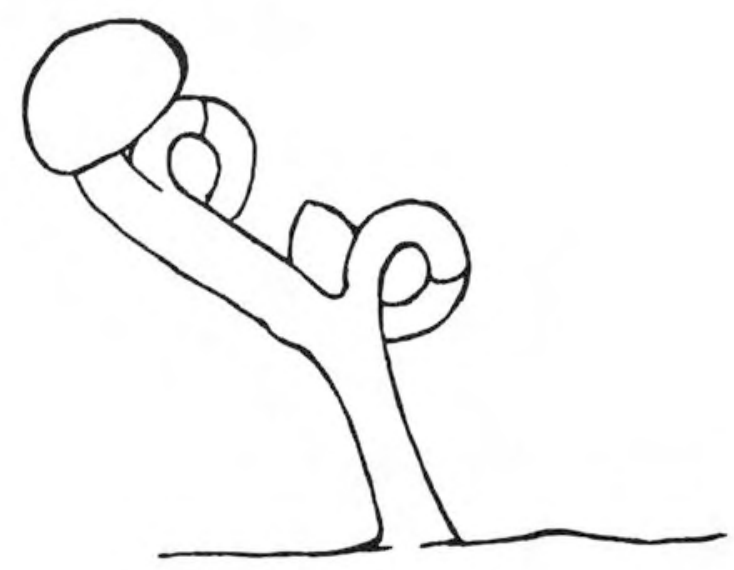

Fig. 17. Vaucheria terrestris - an outgrowing branch with sexual organs. Scale bar $-100 \mu \mathrm{m}$.

are in keeping with data in literature (Starmach 1972; Zauer 1977; Rieth 1980). The range of oogonium dimensions: length 92.8-185.6 $\mu \mathrm{m}$, width 58.0-150.8 $\mu \mathrm{m}$, diverges from this given by Starmach (1972). Oogonium dimensions are of particular interest in the material collected from loc. 16 and 35 ; both the length 145.0-185.6 $\mu \mathrm{m}$ and the width 121.8$150.8 \mu \mathrm{m}$ are the greatest in all populations examined. In other populations the oogonium length is within 92.8-133.4 $\mu \mathrm{m}$, and the width 58.0-104.4 $\mu \mathrm{m}$.

The populations examined could be classified as Vaucheria terrestris var. terrestris and Vaucheria terrestris var. major in keeping with the criteria given by Rieth (1980b).

\section{Vaucheria hamata sensu Götz 1897}

synonym Vaucheria prona Christensen 1970

Vaucheria hamata was collected at 10 localities. Filaments with sexual organs were collected from the localities: loc. 4 - 01.04.92; 03.06.92; loc. 6 - 08.07.94; loc. 8 - 10.05.95; loc. 14 - 14.05.93; loc. 16 - 02.10.94; loc. 17 - 02.10.94; loc. 32 - 20.10.94; loc. 34 - 19.04.95; loc. 38 - 20.10.94; loc. 41 - 03.07.95.

The material was collected from moist soil, muddy embankments of both stagnant and flowing waters, periodically submerged in water, especially in early spring. During the summer, the sites on which samples had been collected dried up and $V$. hamata did not occur.

The species does not show particular seasonal preferences for the development of sexual organs (Fig. 18).

The diameter of vegetative filaments 34.8-75.4 $\mu \mathrm{m}$ and oogonium dimensions: length 58.0-87.0 $\mu \mathrm{m}$, width 46.675.4 , antheridium width 11.6-23.2 $\mu \mathrm{m}$, fall within the range specified in literature (Starmach 1972; Zauer 1977; Rieth 1980). In the populations examined, there were two oogonia placed on both sides of the distinctly twisted antheridium (Fig. 19). In the material collected at loc. 8, a very long branch with sexual organs was observed, three times as long as the typical one. In the population collected at loc. 17 , an outgrowing generative branch was observed.

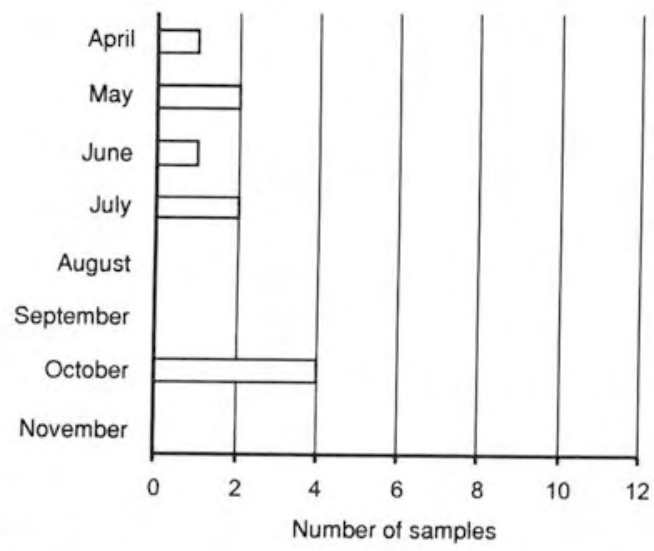

Fig. 18. Vaucheria hamata - the number of samples in which generative filaments were found in the subsequent months.

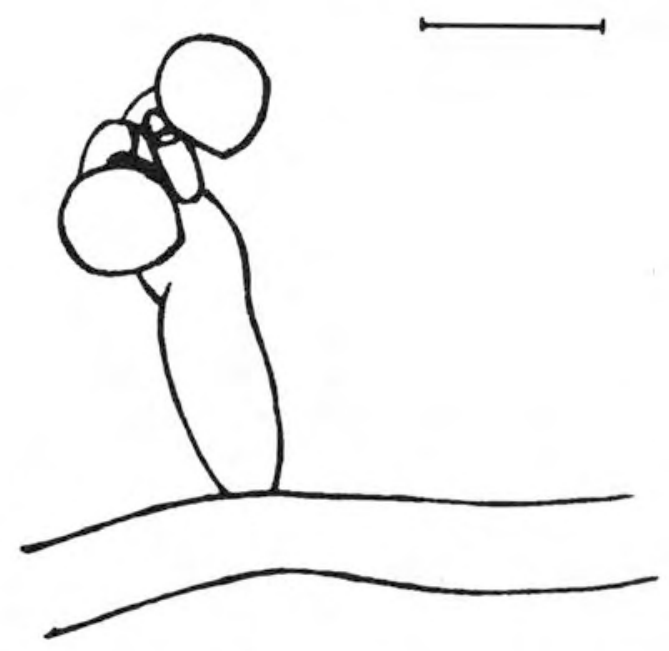

Fig. 19. Vaucheria hamata - a generative branch with two oogonia. Scale bar $-100 \mu \mathrm{m}$.

\section{Vaucheria walzi Rother 1896}

synonym Vaucheria racemosa (Vaucher) de Candolle in de Lamarck et de Candolle 1805

Vaucheria uncinata sensu Rabenhorst 1868

Vaucheria walzi was collected at four localities. Filaments with sexual organs were collected at the localities: loc. 4 - 20.05.92; 24.06.92; loc. 35 - 21.06.95. Generative filaments of $V$. walzi were collected in the littoral zone of stagnant water tanks in late spring. Only vegetative filaments occurred on other sampling days at these localities, and no Vaucheria filaments were found at loc. 4 in July, August in 1993 and 1994.

The species from loc. 9 and loc. 12 was determined on the basis of a culture, after ca. 8 weeks. Samples in which V. walzi developed sexual organs in the culture had also been collected in spring (loc. 9 - 27.04.93, 03.06.93; loc. 12 - 12.04.95). The material from these localities was collected from littoral zones of flowing water, and mats of $V$. walzi were tightly attached to the concrete substrate, and their rhysoids visibly branched out at loc. 9. Vaucheria filaments were not found at these localities during the summer in 1993 and 1994 either.

The diameter of vegetative filaments 64.8-127.6 $\mu \mathrm{m}$ and oogonium dimensions: length 63.8-87.0 $\mu \mathrm{m}$, width 58.0- 
$75.4 \mu \mathrm{m}$, and the antheridium width $23.2-29.0 \mu \mathrm{m}$, are in keeping with those in literature (Starmach 1972; Zauer 1977; Rieth 1980). In the material examined, 2 to 5 , usually 3 or 4 , oogonia occurred, distributed in the manner typical of this species (Fig. 20). A variability of the oogonium distribution along the filament is big, even within one population. Outgrow of the generative branch above the antheridium was observed very frequently (Fig. 21).
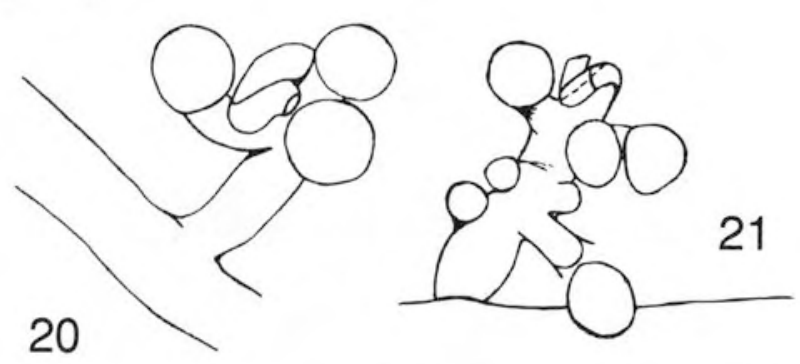

Fig. 20. Vaucheria walzi - a generative branch with three oogonia. Scale bar $-100 \mu \mathrm{m}$.

Fig. 21. Vaucheria walzi - an outgrowing branch with sexual organs. Scale bar $-100 \mu \mathrm{m}$.

\section{Vaucheria woroniniana Heering 1907}

synonym Vaucheria canalicularis (L.) Christensen 1968

V. woroniniana was collected at four localities. Filaments were collected at the localities: 2 - Gieczno I; 9 - Widawka; 14 - Okręt; 37 - Morzyce II. The samples in which filaments with generative organs occurred had been collected in spring from localities: loc. 2 - 15.06.93; loc. 9 - 27.04.93, 06.05.94, 10.05.95; loc. 14 - 12.04.95; loc. 37 -19.04 .95 .

V. woroniniana was identified at localities diversified as far as habitat conditions are concerned. At loc. 2, it grew over a muddy, shaded embankment, periodically flooded by water from the water course that connects fish ponds. At loc. 9, V. woroniniana filaments formed compacted clumps attached to the concrete riverbed in which the current is very rapid. At loc. 14, filaments of the species discussed formed thick, soft mats on the muddy bottom of the concrete canal that carries off water from a fishpond. The material containing filaments with sexual organs was collected from under a thin layer of ice that covered the entire canal. At loc. 37, Vaucheria thalli grew over the muddy pond embankment that is submerged in water in spring and shaded by vascular plants in summer. The material with generative filaments was collected from the moist embankment filaments formed compacted, dark-green clusters.

The material collected at the four localities was diversified as regards the development and structure of sexual organs. At loc. 14, branches with sexual organs consisted of one oogonium, positioned side-wise in relation to the antheridium, which widened and hammer-shaped end was directed towards the oogonium (Fig. 22). The dimensions of the oogonium and antheridium, as well as of the filaments from loc. 14, are in keeping with those specified in literature. Differences in the antheridium structure in the

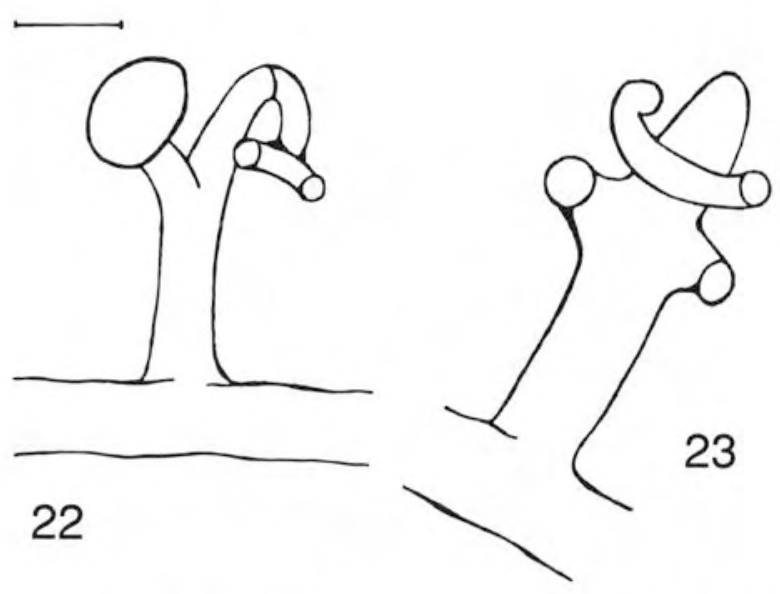

Fig. 22. Vaucheria woroniniana - a generative branch. Scale bar $-100 \mu \mathrm{m}$.

Figs 23. Vaucheria woroniniana - a generative branch with the hammer-shaped widening in antheridia differed. Scale bar -100 $\mu \mathrm{m}$.

material from different localities were also noticed. The width of the hammer-shaped widening in antheridia differed (Fig. 23). The antheridium diameter was measured at the base and beneath the widening. The antheridium diameter is constant within one population, and ranges between 17.4-34.8 $\mu \mathrm{m}(40.6 \mu \mathrm{m})$. Antheridium dimensions were not specified in literature.

Oogonium dimensions, as well as the diameter of $V$. woroniniana filament collected at loc. 9, are bigger than those in the material collected at the other three localities. The filament diameter equaled between 69.6 and $104.4 \mu \mathrm{m}$, while for the other localities it ranged between 46.4-69.6 $\mu \mathrm{m}$; oogonium length from loc. 9 equaled 110.2-133.4 $\mu \mathrm{m}$ and in the other localities 81.2-104.4 $\mu \mathrm{m}$; oogonium width from loc. 9 equaled 98.6-104.4 $\mu \mathrm{m}$; for other localities $63.8-87.0 \mu \mathrm{m}$.

\section{CONCLUSIONS}

Species often encountered in the examined area are: $V$. sessilis at 27 localities, V. terrestris at 18 localities, V. geminata at 17 localities, $V$. hamata at 10 localities. Habitat conditions at the localities at which the species listed above occurred are diversified; preferences as to certain types of localities may be noticed. The best growth and the development of sexual organs were connected with moist soil directly adjacent to aquatic tanks.

Species that occurred rarely at the localities chosen are: $V$. dichotoma and $V$. verticillata at one locality, $V$. aversa and $V$. undulata at two localities, $V$. walzi and $V$. woroniniana at four localities. A limited area in which these species occurred is probably connected with habitat requirements. $V$. dichotoma belongs to halophilous species, and salinity at locality 1 equals ca. $3000 \mathrm{mg} / \mathrm{dm}^{3}$. V. aversa and $V$. undulata prefer waters with increased trophy, similarly to $V$. walzii and $V$. woroninina. The locality at which $V$. verticillata was found belongs to a group of clean rivers.

Co-occurrence of species of the Vaucheria genus was observed at individual localities. In different localities various numbers of the Vaucheria taxa was observed; in 
$32.44 \%$ of localities only 1 taxon was found, in $24.32 \%-2$ taxa, $24.32 \%-3 \operatorname{taxa}, 13.51 \%-4$ taxa, $2.71 \%-5$ taxa, $2.71 \%$ - 6 taxa was recorded. In about $80 \%$ of localities, between one and three species occurred, and in about $20 \%$ of localities, between 4 and 6 . What makes the interpretation of this difficult, however, is that at the localities where 1 to 3 species occurred samples had been collected one or more times for the most part.

On site, filaments of individual species of the Vaucheria genus occurred in varying types of localities, and developed differently in different seasons. A preference towards certain localities where the material containing filaments with generative organs had been found was observed. These were: littoral zones of stagnant waters, embankments of various water tanks and moist soil directly adjacent to aquatic tanks. Vegetative specimens of Vaucheria, however, were collected in waters with rapid current and sexual organs were developed only after some time, between a few days and a few months, of being in a culture. Filaments of Vaucheria that grows in waters with rapid flow, however, on fixed, hard substrate, such as concrete riverbeds, natural or artificial river bars, stones submerged in water continually splashed with water, grow intensely but do not develop sexual organs in these places.

The development of sexual organs in individual species in natural habitats differs throughout the year. On the basis of the observation of the species generative forms of which were collected on site most often or on repeated observations of other species, preferable reproduction periods of these algae during the year may be indicated. For the majority of species, spring is the best period for the development of sexual organs; however, early spring (low water temperatures, e.g. V. aversa, $V$. dichotoma, $V$. terrestris, $V$. woroniniana) and late spring ( $V$. sessilis, $V$. geminata, $V$. walzi) can be differentiated. As for $V$. hamata, it is difficult to determine specifically the period of the development of sexual organs; autumn, however, as the preferred season, is discernible. In order to determine preferred reproduction periods throughout the year for species of the Vaucheria genus more precisely, further observations spread over a span of a few years should be conducted, in relation with physical and chemical properties of the habitat.

Observations of taxonomic features of the Vaucheria genus were conducted on life material in the generative stage, collected directly on site or from the culture. It may be assumed that dimensions of vegetative or generative filaments, measured at the place of the sexual organs, should not be considered as a taxonomic feature of the Vaucheria genus. For $V$. dichotoma, the diameter of the vegetative filament ranged between 86.4 and $226.8 \mu \mathrm{m}$, while for the generative filament between 75.6 and $259.2 \mu \mathrm{m}$, thus the dimension range was almost the same for both filaments. Big differences in diameter of the generative filament within the species $V$. sessilis in populations from one locality but collected on different days (e.g. on 03.06.93 34.8-40.6 $\mu \mathrm{m}$, and on 06.05.94 104.4-145.0 $\mu \mathrm{m}$ ) were observed; yet dimensions of sexual organs in these samples were comparable.

In the populations of $V$. dichotoma, monoaecism and dioecism were observed. In the material examined that contained $V$. aversa filaments, antheridia with a narrowing at $1 / 3$ of their length were observed in different populations apart from antheridia developed in a typical way list- ed in literature. A wide range of oogonium and antheridium dimensions was noticed in $V$. sessilis in the material from different localities, and oogonium dimensions in the case of one locality (12) were smaller than those given in literature. An additional opening, next to typically developed antheridia, was developed in antheridia in the population from one locality (7). An atypical development of sexual organs at the end of filaments was observed. On the basis of the observations carried out to determine the range of variability of the oogonium development where all types of structure, including intermediate forms, occurred within one population and sometimes even on one filament, there are not ground to distinguish variations. A wide range of variability in the type of the generative branch structure was also observed in $V$. geminata. Generative branches with one oogonium and two oogonia, as well as the development of sexual organs at the end of the filament in another case, occurred characteristically in a population, and the number of occurrences was similar. A wide range of oogonium and antheridium dimensions in populations from different localities, not given by all authors cited, was emphasised. The dimension range of $V$. verticillata, identified in one locality (6), was broader than that given in literature. Characteristic generative branches, with three to five turned oogonia, bent in one direction; clearly set this species apart from $V$. gemianta, which used to be considered as its variations. Undulatory vegetative filaments and generative branches were characteristic of $V$. undulata in the material examined, apart from old fragments of the filament the walls of which were visibly thicker and layered following the drying up of the substrate. In the populations examined, generative branches with one oogonium were developed more often than generative branches with two oogonia. Dimension ranges of oogonia in $V$. terrestris in the material from different populations differed significantly, and they equal at two localities (16 and 35): length $145.0-185.6 \mu \mathrm{m}$, and width $121.8-150.0 \mu \mathrm{m}$; the dimension range in the other localities was: length 92.8-133.4 $\mu \mathrm{m}$, width 58.0-104.4 $\mu \mathrm{m}$. Such a clear differentiation of oogonium dimensions may serve to distinguish two variations in the material examined, in keeping with Reith (1980): $V$. terrestris var. terrestris and $V$. terrestris var. major. In the material examined that contained $V$. hamata filaments, very long branches, approximately three times as long as typical ones occurred apart from typical generative branches in the population from one locality (8). A differing number, from 2 to 5 and differing distribution of oogonia along the generative branch connected with it was significant in the material examined, even within one population of $V$. walzi. Outgrow of the generative branch, sometimes even more than one, very often occurred in this species. Particular attention was drawn to the width of the hammer-shaped widening of the antheridium in V. woroniniana, which differed in individual populations. The antheridium width was measured both at the basis of the antheridium and directly beneath the widening. The measurements have shown that the antheridium diameter ranged between $17.4 \mu \mathrm{m}$ and $34.8 \mu \mathrm{m}$ in the populations examined.

The range of significant features in the taxonomy of the Vaucheria genus is in keeping with that specified by Starmach (1972), Zauer (1977), Reith (1980) for the majority of the species examined. The features that were not specified earlier and observed in this study for some 
species are indicative of a great variability that may serve to distinguish new taxa on the level of variations after further research.

\section{LITERATURE CITED}

AMIROWICZ A. 1980. Vaucheria canalicularis (L.) Christensen 1986 z Potoku Bolechowickiego koło Krakowa. Fragm. Flor. Goebot. 26, 2-4: 355-362.

AMIROWICZ A. 1983a. Vaucheria species in the neighbourhood of Cracow - Gatunki woszerii z okolic Krakowa. Fragm. Flor. Geobot. 29, 3-4: 465-474.

AMIROWICZ A. 1983b. Woszerie i możliwości ich badania. Wszechświat 10: 225-228.

KADŁUBOWSKA J.Z. 1961. Glony zbiorników wodnych Łodzi i okolicy. ŁTN, 71: 1-164.

KADŁUBOWSKA J.Z. 1964. Okrzemki rzeki Pilicy i ich znaczenie w ocenie czystości wody. ŁTN: 1-48.

KADŁUBOWSKA J.Z., LIGOWSKI R., RAKOWSKA B., MAKSYMIUK Z. 1981. Flora glonów Bełchatowskiego Okręgu Przemysłowego. Acta Univ. Lodz., Folia bot., 1: 257-291.

KALINOWSKA-KUCHARSKA E., LIGOWSKI R. 1976. Glony dorzecza Pilicy na odcinku Koniecpol - Tomaszów Mazowiecki. Acta Univ. Lodz., Folia bot., II, 2: 207-240.

KAWECKA B. 1971. Strefowe rozmieszczenie zbiorowisk glonów w potokach Polskich Tatr Wysokich. Acta Hydrobiol. 13, 4: 393-414.

KUCHARSKI L. 1993. Szata roślinna gleb hydrogenicznych Kujaw Południowych. Acta Univ. Lodz., Folia bot. 10: 69-92.

LIGOWSKI R. 1986. Sessile algae in lower sections of the main tributaries of the Widawka River. Acta Univ. Lodz., Folia bot. 4: 171-202.

LIGOWSKI R. 1988. Sessile algae of the Widawka River. Acta Univ. Lodz., Folia limnol. 3: 19-49.

LIGOWSKI R. 1991. Frekwencja glonów osiadłych w rzece Bobrówce oraz w stawach zasilanych wodą z tej rzeki (Polska Centralna). Acta Univ. Lodz., Folia limnol. 4: 141-186.

MAKSYMIUK Z. 1970. Hydrografia dorzecza Grabi. ŁTN, Acta Geograph. Lodz. 25: 1-104.

MROZIŃSKA T. 1957. Glony nitkowate porastające rośliny wyższe w stawach rybnych Gospodarstwa Doświadczalnego Ochaby. Fragm. Flor. Geobot. 3: 141-152.
MROZIŃSKA T. 1991. Przewodnik algologiczny po Wyżynie Krakowsko-Częstochowskiej na tle minionych epok geologicznych i w okresie współczesnym. Instytut Botaniki im. W. Szafera PAN Kraków: 1-32.

NAWRAT B. 1993. Jesienno-zimowe okrzemki osiadłe na niciach Vaucheria w potoku Kluczwoda koło Krakowa. Fragm. Flor. Geobot. 38 (2): 715-736.

PLIŃSKI M. 1969. Okrzemki słonego źródła w Pełczyskach pod Ozorkowem. Zesz. Nauk. Uniw. Łódz., Nauk. Mat. Przyr. Ser. II, 31: 123-136.

PLIŃSKI M. 1973. Glony solnisk Podłęczyckich. Monogr. Bot. 39: 1-89.

RAKOWSKA B. 1984. Glony rzeki Rawki. Acta Univ. Lodz., Folia bot. 3: 283-320.

RIETH A. 1980. Xanthophyceae. 2. Teil. In: Ettl H., Gerloff J., Heynig H. Süßwasserflora von Mitteleuropa. VEB Gustav Fischer Verlag, Jena: 1-147.

SIEMIENIAK D. 1983/1984. Epipelic algae in marginal parts of the Przeczyce resrvior and of neighbouring sectors of the $\mathrm{Ri}-$ ver Czarna Przemsza (Upper Silesia). Acta Hydrobiol. 25/26, 1: 51-66.

SKALNA E. 1973. Glony wywierzyska krasowego w Jerzmanowicach (Wyżyna Krakowsko-Częstochowska). Fragm. Flor. Geobot. 19, 3: 343-348.

SKALNA E. 1979. Glony ziemne występujące w uprawach niektórych warzyw w Prusach koło Krakowa. Fragm. Flor. Geobot. 25, 4: 607-648.

STARMACH K. 1972. Chlorophyta III. Zielenice nitkowate. In: Starmach K., Siemińska J. Flora Słodkowodna Polski 10. PWN, Warszawa - Kraków: 1-750.

WOLOWSKI K. 1992. First record of Vaucheria species (Xanthophyceae, Vaucheriaceae) from the gorge of Kluczwoda in southern Poland. Fragm. Flor. Geobot. 37, 2: 535-538.

ZAJĄC A. 1978. Założenia metodyczne „Atlasu rozmieszczenia roślin naczyniowych w Polsce". Wiad. Bot. 23, 3: 145-155.

ZAUER L.M. 1977. Sifonovyje vodorosli. Flora sporovych rastienii CCCP, t. 10. Nauka, Leningrad.

ŻELAZNA-WIECZOREK J., KADŁUBOWSKA J.Z. 1994. Występowanie przedstawicieli rodzaju Vaucheria De Candolle na terenie Polski Środkowej i Śląska Opolskiego. ŁTN. Sprawozdania z Czynności i Posiedzeń Naukowych, T. XLVIII: $237-$ -240 .

\title{
RODZAJ VAUCHERIA Z WYBRANYCH OBSZARÓW POLSKI
}

\author{
STRESZCZENIE
}

Na podstawie badań prowadzonych w latach 1989-1995 na 42 stanowiskach wyznaczonych na terenie Polski Środkowej, Śląsku Opolskim i pojedynczych rozrzuconych na terenie kraju, przedstawiono obserwacje cech morfologicznych, rozmieszczenie i preferencje siedliskowe 10 gatunków rodzaju Vaucheria. Określono preferencje wobec pory roku i warunków siedliskowych dla tworzenia organów generatywnych, stanowiących podstawę w taksonomii tego rodzaju. Gatunkami często występującymi w zebranym materiale były: $V$. sessilis, $V$. terrestris, $V$. geminata, $V$. hamata. Natomiast $V$. dichotoma, $V$. verticillata, $V$. aversa, $V$. undulata, $V$. walzi, $V$. woroniniana to gatunki spotykane sporadycznie w czasie prowadzenia obserwacji.

SŁOWA KLUCZOWE: Vaucheria, zmienność morfologiczna, występowanie w Polsce, preferencje siedliskowe. 